ELORE (ISSN 1456-3010), vol. $12-1 / 2005$.

Julkaisija: Suomen Kansantietouden Tutkijain Seura ry. Taitto: Jukka Talve.

[http://cc.joensuu.fi/ /oristi/1_05/kai1_05.pdf]

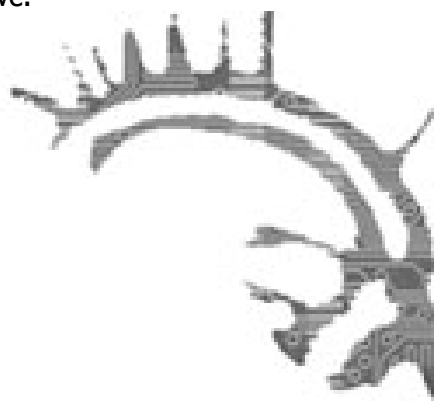

\title{
MATKAKIRJE SUOMALAISKESKUKSESTA \\ KANADAN SYDÄNMAILLA
}

Annikki Kaivola-Bregenhøj

Toista metriä lunta, aamuisin pakkasta runsaat 30 astetta. Tässä ulkoiset puitteet kaukaisesta Thunder Bayn kaupungista. "Kaukana" se on tosin vain Euroopasta, sillä Kanadassa etäisyydet eivät ole niin kummallista, koska tässä suuressa maassa kaikki on kaukana. Thunder Bay on lähellä USA:ta, Lake Superiorin toisella rannalla. Asukkaita kaupungissa on noin 113 000, ja itse asiassa Thunder Bay on kahden rinnakkaisen ja aikaisemmin keskenään kilpailleen Port Arthurin ja Fort Williamin yhdistämisen tulos. Kuntaliitos siis! Sen asukkaat ovat pohjois-amerikkalaiseen tapaan lähtöisin eri puolilta Eurooppaa, ja kaikki tuntevat juurensa vaikka ovat nyt vakaasti kanadalaisia. Täällä on myös mittava intiaaniväestö, josta käytetään nimitystä "First Nation people".

\section{FinNish ChaIR}

Talvilukukauden 2005 olen ollut Suomen oppituolin haltija, Finnish Chair, Lakeheadin yliopistossa. Yhdessä mieheni ja lähimmän kollegani Carstenin kanssa olemme opettaneet 36 tunnin mittaisen kurssin "Oral Culture of Finland and Scandinavia". Kurssilaisemme ovat olleet 2.-4.vuoden opiskelijoita, joista osa on kulttuuri-antropologiaa lukevia, osa esimerkiksi suomalaistaustansa takia kiinnostuneita tästä aihepiiristä. Ilmeisesti vain yksi opiskelijoistamme osaa vanhempiensa kieltä, suomea. Joukossa on myös sosiaalialaa ja sairaanhoitoa opiskelevat tytöt, juridiikkaa kohti pyrkivä nuori nainen, taiteita ja urheilua opiskelevia, sekä "harvinaisia kieliä" lukeva poika, jonka listalla ovat saksa, suomi ja intiaanien kieli, sekä Oulusta vaihto-oppilaana oleva arkeologian opiskelija. Täällä suomen kielen opetuksesta vastaa Jari Leinonen, ja Suomen historian erityiskurssi on suunnitteilla ensi vuodeksi historian laitokselle. 
Koska luennoimme antropologian laitoksessa ja yliopistossa ei opeteta folkloristiikkaa, tiesimme odottaa "erilaista" kuulijakuntaa. Tuskin kuitenkaan aivan näin monitaustaista. Antropologian laitoksessa on kuusi professoria (2 arkeologian, 2 fyysisen ja 2 kulttuuriantropologian professoria), teknikko sekä nuorempia, suomalaisittain tuntiopettajia. Lakeheadissa antropologian opiskelijat voivat suorittaa vain $\mathrm{BA}$ ja BSc-tutkinnot, jotka vievät opiskelijan taustasta riippuen 3-4 vuotta. Jotkut suorittavat vielä Honours BA (tai BSc) arvosanan, jonka turvin on helpompi päästä jatkamaan. Maisteritutkinto on tehtävä muualla, ja sitä on erikseen pyrittävä suorittamaan. Laitoksen nuorista tutkijoista yksi tekee fyysisen antropologian alaan liittyvää väitöstutkimusta Ouluun sikäläisten hautalöytöjen valossa. Oulu ja Rovaniemi ovat Lakeheadin ystävyys-yliopistoja, ja useampikin tutkija näyttää valmistelevan eri alojen väitöskirjoja Ouluun. Oulusta on tänäkin lukuvuonna joitakin vaihto-opiskelijoita Lakeheadissa.

\section{OPISKELU YLIOPISTOSSA}

Opintojen rakenne on melko erilainen kuin Suomessa. Luentokursseja on paljon ja kirjatenttejä vain poikkeuksellisesti. Kuulemani mukaan joku 4. vuoden opiskelija on korvannut luentokurssit kirjoilla, joiden pohjalta hän kirjoittaa esseen kerran kuukaudessa. Pari nuorempaa kollegaamme Memorial-yliopistossa St.Johnsissa (New Foundland) nauroivatkin, että kaikki opiskelijat eivät edes tiedä, missä kirjasto on, koska istuvat aina tiiviisti vain luennoilla. Luentokurssi ei kuitenkaan ole vain "istumista", silla siihen kuuluu vähintään kaksi koetta ja mahdollinen harjoitustehtävä. Kokeet arvostellaan 0-100 skaalalla ja ilmoitetaan prosentteina. Lopullisessa arvosanassa on 40 prosenttia heikommin menneestä ja 60 prosenttia paremmasta kokeesta, ja lisäksi valmistellusta esiintymisestä luennolla saa lopputulokseen 3 prosentin lisän. Jos ei läpäise kokeita tyydyttävästi, voivat 40-49 prosenttia saaneet uusia kokeensa, muiden on suoritettava koko kurssi uudelleen.

Opiskelu on täällä maksullista. Kysyessäni sen hintaa yksi opiskelijani kertoi lukuvuoden maksavan viisi tuhatta Kanadan dollaria (noin 3200 euroa). Päälle tulevat oppikirjat, asuminen ja eläminen. Lukukausimaksuun sisältyy 6 kurssia, mutta lisäkursseista on maksettava erikseen. Tähän asti seniorit ovat saaneet opiskella ilmaiseksi, ja meidän kurssillamme oleva seniori on yksi kurssin parhaita. Opintotukea ei Kanadassa ole, joten työt, vanhempien tuki ja pankkilaina ovat tarpeen. Yliopistot ovat erihintaisia. Opiskelemaan sitä vastoin on helpompi päästä kuin Suomessa, sillä esimerkiksi antropologian opinnot voi aloittaa kuka tahansa, jonka koulutodistuksen keskiarvo on suomalaisittain 6. Yliopistot ovat laskeneet sisääntulo-keskiarvojaan, sillä kilpailu opiskelijoista on kovaa. Yliopistot saavat valtion tukea opiskelijamääriensä perusteella, ja professorikin voi joutua puhelimitse värväämään opiskelijoita omaan yliopistoonsa.

Kaikki "vaihtarit", joiden kanssa olen keskustellut, ovat saaneet joko CIMOlta tai muualta avustuksia, tosin matkat lienee pakko rahoittaa itse. Elämi- 
nen on jonkin verran halvempaa kuin Suomessa, mutta toisaalta oululaistyttö kertoi maksavansa neljän hengen solu-asunnosta 2500 dollaria (noin 1600 euroa) lukuvuoden aikana. Asunnon vuokra oli korkeampi kuin hänellä Suomessa ja asumisen taso heikompi. He ovat kuitenkin tyytyväisiä siihen, että tuli lähdettyä vaihtoon.

\section{Paikallista folkioristiIKKaA}

Carsten ja minä vierailimme lukuviikon aikana Memorial-yliopistossa St. Johnsissa, jonka vastaava viikko oli vasta tulossa. Siellä on iso folkloristiikan laitos, jonka henkilökuntaluettelossa näen 11 nimikkeiltään erilaista professoria (täällä professori etenee "assistant"-vaiheesta "associate"-professoriksi, ja lopuksi hän voi saavuttaa "täyden professuurin"). Koska yliopistojen niukka rahatilanne tunnetaan täälläkin, lupauduimme pitämään kumpikin korvauksetta 3 luentoa. Olihan se tiivis 3 päivän vierailu, mutta se kannatti. Saimme vastalahjaksi folkloristiyleisön, joka tiesi, mistä puhumme ja antoi sen mukaista palautetta. Tosin "omatkin opiskelijamme" ovat loppua kohti alkaneet keskustella. Memorial-yliopistosta tunsimme entuudestaan Paul Smithin (mm. kiertueperinne ja kaupunkitarinat) ja Martin Lovelacen (mm. balladit), mutta Paulin riemukkailla nyyttikesteillä (lue: mahtavat illalliset) tapasimme koko joukon uusia, nuoria ja vanhoja folkloristeja. Tunsimme olevamme henkisesti kotona. Jos folkloristiikan opiskelija haluaa suunnata Kanadaan, oikea osoite onkin ilman muuta Memorial, missä on monen koulukunnan ja perinteen spesialisteja. Siellä myös jatko-opiskelijat pitävät luentokursseja ja saavat näin rahaa jatko-opintoihinsa. Memorialissa on siis mahdollisuus tutustua myös nuoriin tutkijoihin.

Opetus Lakeheadin yliopistossa on vain osa Suomen oppituolin toimenkuvaa. Finnish Chair (millä nimellä viranhaltijaa kutsutaan virallisesti) opettaa vähemmän kuin muut, sillä normaalisti professorilla on viisi yhden lukukauden kurssia vuodessa. Tosin minä olen tänä aikana kirjoittanut myös yliopiston minulta pyytämän asiantuntijalausunnon, mikä liittyy professuurissa ylenemiseen. Jos professori saa apurahaa, hän voi ostaa sillä jonkun toisen luennoimaan kaksi kurssiaan. Näin jää aikaa tutkimukselle. Finnish Chair on sen sijaan velvoitettu pitämään yhteyksiä suomalaisyhteisöön. Yhteyksiä olemme Carstenin kanssa pitäneet käymällä paikallisten suomalaisten tilaisuuksissa ja kertomalla muiden muassa kahden suomalaislehden haastattelussa, että olemme halukkaita esiintymään. Menoja ja sosiaalista elämää onkin riittänyt. Kalevalanpäivän kunniaksi pidin suomalaisessa kirkossa jumalanpalveluksen jälkeen esitelmän, ja yhdessä olemme esiintyneet englanniksi yliopiston luentosarjassa, jonka kaikki 10 esitelmää liittyivät jotenkin Suomeen. 


\section{THUNDER BAY - UKKOSLAHTI}

Kuinka moni mahtaa tietää Thunder Bayn suomalaisyhteisöstä? Itse tiesimme aluksi todella vähän, mutta Carsten täydensi tietojamme internetin avulla ja Terttu Kaivola muistutti, että Kalevalaseuran vuosikirjasta löytyy Maisa Martinin artikkeli Elämää Ukkoslahdessa. Silti hämmästyksemme oli melkoinen, kun jo ensimmäisenä päivänä kuulimme kadulla suomea. Olimme osuneet suoraan kaupungin vanhaan suomalaiskeskukseen, Bay-kadulle, missä on yhä toiminnassa 5 suomalaisen omistajan liikettä, "Työväen temppeli" eli nykyisin nimeltään Finlandia-Club ja koko kaupungin tuntema Hoito-ravintola. Saman kadun varrella on Canadan Sanomien toimisto, Suomen konsulaatti, ja lähikaduilla leipomo "Harri Bakery" sekä Bay Credit Union -pankki, missä voi asioida myös suomeksi. Joskus suomalaisia on arveltu olevan noin 12 prosenttia Thunder Bayn asukkaista, mutta nykyään on vaikea tietää, millä suomalaisuus mitataan: sukunimelläkö, kielellä vai halulla identifioitua suomalaisryhmään. Koska jotkut ovat jo kolmannen polven suomalaisia, ei mikään yksittäinen kriteeri ole aukoton.

On ollut mielenkiintoista huomata, että täällä suomalaisuuteen ei liity negatiivista juonnetta, minkä kohtaa liikkuessaan esimerkiksi Ruotsissa tai Venäjällä asuvien suomalaisten parissa. Syitä on varmaan monia, mutta yksi selitys liittyy kaupungin monikulttuurisuuteen. Lyhyessä ajassa olemme itsekin kohdanneet suomalaisten lisäksi taustaltaan ruotsalaisen, skotlantilaisen, ukrainalaisen, ranskalaisen ja italialaisen Kanadan kansalaisen. Kun kyselin ruotsalaisjuuria tutkivalta Elinor Barrilta, onko etnisten ryhmien välillä ollut hierarkiaa, hän totesi näin olleen. Asteikossa korkeimmalla olivat britit, jotka eivät tänne muuttaessaan edes pitäneet itseään siirtolaisina, ja sitten seurasivat läntisen Euroopan maahanmuuttajat. Pohjilla oli itäinen Eurooppa, ja tänne alimpien ryhmien läheisyyteen luokiteltiin myös suomalaiset ja italialaiset. Jo ennen ensimmäistä maailmansotaa tänne tuli parituhatta suomalaista, ja uusi siirtolaisuusaalto rantautui 1950-luvulla. Kansallisuustausta on täällä tärkeä ja helppo puheenaihe, mistä kaikki kertovat mielellään. Monikulttuurisuus tuntuu meidänkin arjessamme siten, että ostamme lähikatujen kaupoista niin suomalaisia (karjalanpiirakat) kuin italialaisiakin (juusto ja leivokset) herkkuja. Vielä on ehdittävä puolalaisten talolle ostamaan kaaliruokia, joiden tuoksu tulee perjantaisin bussipysäkillemme. Thunder Bayn suomalaisuutta olisi todella kiinnostava tutkia syvällisemminkin, mutta siitä vastaa kollegamme professori Raija Warkentin, jonka monien tutkimusaiheiden joukossa ovat Kanadan suomalaisten saunatavat ja niihin liitetyt terveyskäsitykset.

Olen neljäs Lakeheadin yliopiston Suomen oppituolin haltija, ensimmäinen nainen ja ensimmäinen folkloristi. Edeltäjäni ovat edustaneet politiikan tutkimusta, insinööritiedettä ja sosiologiaa. Finnish Chair saa kiinnityksen yhden lukukauden ajaksi, ja hän voi edustaa eri tieteenaloja ja työskennellä omaa alaansa lähellä olevassa laitoksessa. Opetus- ja tutkimustyön ohella hän osallistuu suomalaisyh- 
teisön toimintoihin ja antaa tarvittaessa asiantuntija-apuaan. Yliopisto ja erityisesti Antropologian laitos ovat ottaneet meidät hyvin vastaan, ja meidät on esitelty myös yliopiston kotisivuilla julkaistavassa Agora-lehdessä.

Chair in Finnish Studies -toimintaa rahoittaa säätiö, jonka varoja on kerätty vuodesta 1988 lähtien. Rahastoa ovat kartuttaneet niin viralliset tahot, muiden muassa Opetusministeriö ja Lakeheadin yliopisto ja monet suomalaisjärjestöt, mutta myös aivan tavalliset "rivikansalaiset", joille yliopisto on itse asiassa hyvin kaukainen maailma. Olenkin miettinyt, miten olla niiden ihmisten käytettävissä, jotka eivät astu yliopiston ovesta sisälle. Sen osoitti erittäin kiiinnostava Suomeen liittyvä luentosarja, jota vain kourallinen ei-akateemisia suomalaisia uskaltautui kuuntelemaan. Kirkko ja "Työväen temppeli" ovat selkeästi etnisiä areenoja, joissa kohtaa suomalaisia. Nyt eletään aikaa, jolloin suomi ja englanti ovat rinnakkain käytössä. Mutta toisen polven suomalaiset eivät kaikki osaa vanhempiensa kieltä, ja kolmas polvi on jo englanninkielinen. Kirkossa on jo kaksi jumalanpalvelusta, ja "kielisiä" (= kaikki ne, jotka puhuvat muuta kuin suomea) varten esimerkiksi kevyt iltapäiväkonsertti "Työväen temppelissä" esiteltiin kummallakin kielellä. Hoito-ravintolan (alkuaan perustettu työläisten tarpeisiin) ruokalista on kaksikielinen, mutta nuori tarjoilija puhuu mieluiten englantia.

Jää on miltei sulanut Lake Superiorista, ja ensimmäiset rahtilaivat ovat lipumassa Port Arthurin satamaan. Kanadan preerioiden viljasta kulkee 70 prosenttia tämän sataman kautta maailmalle. Fort Williamin asemalta lähtee tavarajuna, joka voi vetää jopa 140 viljavaunua. Henkilöliikennettä ei raiteilla enää ole. Yhteys muuhun maailmaan tapahtuu lentäen: Toronto on lähin yhteyskenttä ja sinne on runsaan tunnin lento. Maanteitse matka kuulemma taittuu 13 tunnissa ellei pidä taukoja. Thunder Bayn rajoilla ovat sellaiset kylät kuin Finmark, Lappe ja Intola, sitten alkavatkin pitkät metsätaipaleet. Kanada on suunnattoman suuri.

\section{FT Annikki Kaivola-Bregenhoj on Turun yliopiston folkloristiikan profes- sori (emerita).}

